\title{
Eden Project - the Cornwall Peninsula peculiarity
}

\author{
Projekt Eden - osobliwość Półwyspu Kornwalijskiego
}

\author{
Elżbieta Baczyńska ${ }^{1}$, Marek W. Lorenc ${ }^{2}$ \\ ${ }^{1}$ Wroctaw University of Environmental and Life Sciences, Faculty of Environmental Engineering and Geodesy, \\ pl. Grunwaldzki 24a,50-363 Wrocław, e-mail: elzbieta.baczynska@up.wroc.pl \\ ${ }^{2}$ Wroctaw University of Environmental and Life Sciences, Institute of Landscape Architecture, \\ pl. Grunwaldzki 24a,50-363 Wroctaw,e-mail: marek.lorenc@up.wroc.pl
}
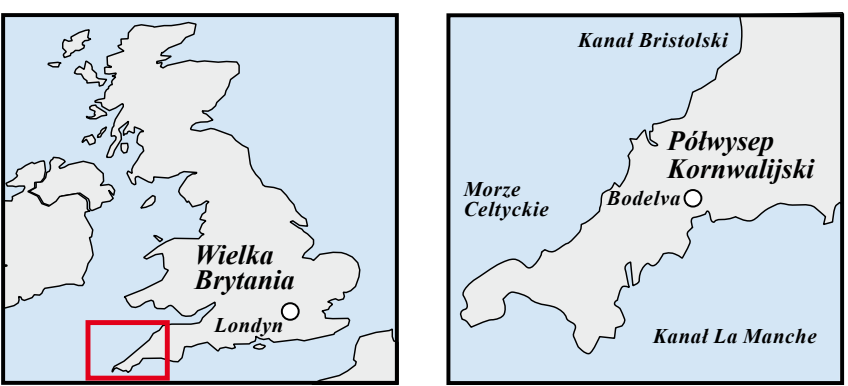

Abstract: The Eden Project-the largest natural scientific complex - was established in 2001 in the surroundings of Bodelva situated in the southern part of Cornwall (Great Britain). It was created in a kaolin pit closed down in the XIXth century. This venture has three main functions: natural, educational and touristic. The project presents unusually interesting and original architecture. Under light-transmitting, semicircular domes there are various ecosystems called biomes which differ from the external environment. The entire project consists of the following parts: the Mediterranean biome, the rainforest biome, a unit called "the Core" and the visitor centre. The area where all the buildings are located is covered by the external biome. The Eden Project is a huge educative institution which reflects processes occurring in the nature. The aim of this venture is, above all, education of ecological aspects concerning life on the Earth and presentation of the necessity to preserve the biodiversity. Since its opening, the Eden Project has been visited by 1.2 million tourists every year. Key words: quarry, mining landscape, tourist attractions, Eden Project, Cornwall

Treść: W okolicach miejscowości Bodelva, położonej w poludniowej części Kornwalii (Wielka Brytania), w 2001 roku powstat Projekt Eden - największy kompleks przyrodniczy, utworzony w nieczynnym od XIX wieku wyrobisku pozostatym po odkrywkowej eksploatacji kaolinu. Przedsięwzięcie to petni trzy główne funkcje: przyrodniczq, edukacyjna i turystycznq. Projekt Eden charakteryzuje niezwykle ciekawa i oryginalna architektura. Sktadaja się na nia przepuszczajace światto pótkuliste koputy, pod którymi znajduja się odmienne względem siebie i względem środowiska zewnętrznego ekosystemy zwane biomami. Na całość projektu składajq się: biom śródziemnomorski, biom lasu deszczowego, a także obiekt zwany „Jadrem” oraz budynek centrum dla odwiedzajacych. Teren, na którym znajduja się wszystkie budynki, okala biom zewnętrzny. Projekt Eden to olbrzymia instytucja edukacyjna, która odzwierciedla relacje zachodzace w naturze. Celem tego przedsięwzięcia jest przede wszystkim nauczanie o ekologicznych aspektach zwiqzanych z życiem na Ziemi oraz ukazanie konieczności zachowania bioróżnorodności. Od czasu otwarcia Projekt Eden corocznie odwiedza 1,2 mln turystów.

Stowa kluczowe: kamieniołom, krajobraz górniczy, atrakcje turystyczne, Projekt Eden, Kornwalia

\section{Introduction}

The discussed area is located on the tip of the south-west part of Great Britain called the Cornwall Peninsula which is $250 \mathrm{~km}$ long and $100 \mathrm{~km}$ wide. This peninsula is bordered from the north by the Celtic Sea and the Bristol Channel, from the south by the English Channel. Cornwall presents one of the most diversified landscapes of Great Britain. The coastline reveals large diversity of ria forms, high cliffs and picturesque bays deeply incised landwards - popular destinations for many tourists (Fig. 1 and 2). The peninsula is situated in the zone of temperate marine climate and that is why Cornwall is the warmest region of the British Islands. The southern tip of the peninsula is often called the Cornish Riveria. This place is abundant in beautiful parks and gardens full of exotic plants. It is possible because the average annual temperature amounts to 10-12 degrees Celsius. Typical Cornish landscapes are vast moors and peat bogs, whereas forests are absent.

Cornwall population amounts some 515,000 people. Most of them are elder or retired persons. Previously, the local economy was based on mining, especially on extraction of tin. Ore mining in this area has a very long and complex history. Tin extraction has started here about 3,500 years ago. The peak of tin mining took place in the XIXth century, which was affected by the discovery of the steam engine. It is worth mentioning that one of the first Watt's steam engines was installed in one of the Cornish mines (Fig. 3). In 1998 final decline of mining industry and closure of the last mines took place (Schwartz \& Lorenc, 2011). At that time, due to difficult economic situation, many mining specialists emigrated. This problem existed even earlier - the number of people who left Cornwall in the years 1815-1915 amounts from 250,000 to 500,000 (Schwartz, 2006). They moved to both, the North and the South America, Africa, Australia or New Zealand. Buildings of very characteristic architecture, hosting huge steam engines which drove the draining systems and vertical transport at the mines, prove that almost everywhere in the world where tin was extracted miners used 
technical solutions which have originated from Cornwall (Lorenc \& Cocks, 2008) (Fig. 4).

Currently, Cornwall is mainly a tourist destination and its economy is based on tourism. In the other parts of the peninsula, where vast pastures occur, agriculture and breeding prevail. Each year tourists are attracted by many lovely towns, bays or cliffs. One of these places offering an interesting form of entertainment is the Eden Project visited by large numbers of tourists from all over the world.

\section{Geology}

The geology of the Cornwall Peninsula is reflected in the morphology of the area: all elevations are built from hard rocks which are relatively resistant to erosion, whereas depressions are made from rocks of much lower resistance. The examples of such elevations are Dartmoor and Exmoor with the highest point: High Willhays (621 m above sea level).

The great river Tamar is a natural border separating the county of Cornwall from the rest of Great Britain, both geographically and culturally. However, geological structures and units continue from the eastern part of the peninsula further to the county of Devon.

The geology of this part of Great Britain is quite diversified, however, most of the rocks exposed at the surface are Devonian sedimentary formations (both the stratotype and the name of this period come from the nearby county of Devon) with minor carbonates and many intrusions of Variscan granitoids originating from the turn of the Carboniferous and the Permian (Fig. 5).

The Cornwall Peninsula is divided structurally into the two parts separated by a large shear zone called the Start Perranporth Line (SPL), which runs almost latitudinally about $10 \mathrm{~km}$ south from the line Newquay - St. Austell. North from this line there are Devonian slates and mudstones with intercalations of limestones, which in some areas were transformed into marbles as a result of regional metamorphism. More marbles as well as calc-silicate rocks transformed during thermal metamorphism can be found in contact zones with the granitoids (Bristow, 1996).

A completely different lithostratigraphy is observed south from the SPL line. There are parautochthonous formations related to the occurrence of an active collision zone represented by grey slates, sandstones and turbiditic mudstones accompanied by sedimentary breccias resulting from submarine landslides. Moreover, there are also allochthonous formations - nappes thrusted from the southeast. Their oldest part is an olistolith composed of Ordovician quartzites and pillow lavas, whereas the younger part is built of sandstones, turbidites and limestones with flints. The Lizard Complex is a different unit: it is an ophiolite characteristic for such a tectonic regime. In embraces characteristic magmatic rocks: mantle peridotites, dunite cumulates, gabbros, wide basic dykes and pillow lavas. Erratics of limestones, quartzites and cherts can be found in these rocks together with seafloor volcanics (op. cit.).

On both sides of the SPL tectonic line Devonian sediments are accompanied by many volcanic rocks showing typical
MORB (Mid-Ocean Ridge Basalts) geochemical signature.

Carboniferous formations occur only in the eastern part of the peninsula and are represented by slates, mudstones, sandstones and limestones.

Moreover, all formations on both sides of the SPL line are cut by many intrusions of Variscan granites surrounded by vast zones of contact metamorphism which products are hornfelses commonly encountered in the area. Mineral and chemical compositions of these rocks are inhomogeneous, which indicates both the melting of Devonian and Lower Carboniferous sediments enclosing the intrusions as well as deep-sourced magmas. It means that apart from biotite granites with large, directionally arranged crystals of potassium feldspar there occur also two-mica granites, granites with tourmaline and leucogranites (Lorenc, 1994).

During and after the emplacement granite intrusions not only caused thermal metamorphism in the enclosing rocks but were also subjected to transformations and were the source of mineralization. From the economic point of view, ore mineralization was very important. Rich deposits of tin and copper have been mined in Cornwall for more than 3000 years. The second Cornish wealth was white kaolin resulting from the weathering of one of the granite types. Kaolin was used as a raw-material for the production of high-quality porcelain. Particularly high-grade kaolin deposits in Cornwall are related to one of the younger granites located north from St. Austell. This valuable clay was extracted in many open pits. One of such excavations, which has been inactive for years, was assigned for a different purpose which turned out to be a wise step as it made Cornwall world-famous and as it attracts over 1 million tourists a year.

\section{Attractions of the Eden Project}

The number of grounds left after exploitation, which are utilized in an unconventional way is still growing due to a constantly increasing demand for new, unique forms of entertainment. The most common method of development of closed quarries is to transform them into water reservoirs or woodlands, however, the changing social-economic demand forces the search for new solutions (Krawczyk \& Lorenc, 2010).

Post-mining areas do not need to be considered as irretrievably lost in the case of industrial stones. Such objects have high potential and are more and more often transformed into various entertainment parks, amphitheaters, nature reserves and educational centres. The term „transformation” means in this case an adoption of the area left after exploitation to a new function, using its natural attractions as well as anthropogenic elements originating from the operation perion (Pietrzyk-Sokulska, 2005). However, "transformation" is a universal term (op. cit.) as it combines the land reclamation with the development (Skoczylas, 2008).

The Eden Project was established as a result of adapting the ground to the new functions. Although, most of the evidences for the existence of the quarry have faded away, there are information boards reminding us at every step the skills of the miners and the high level of their performance. 


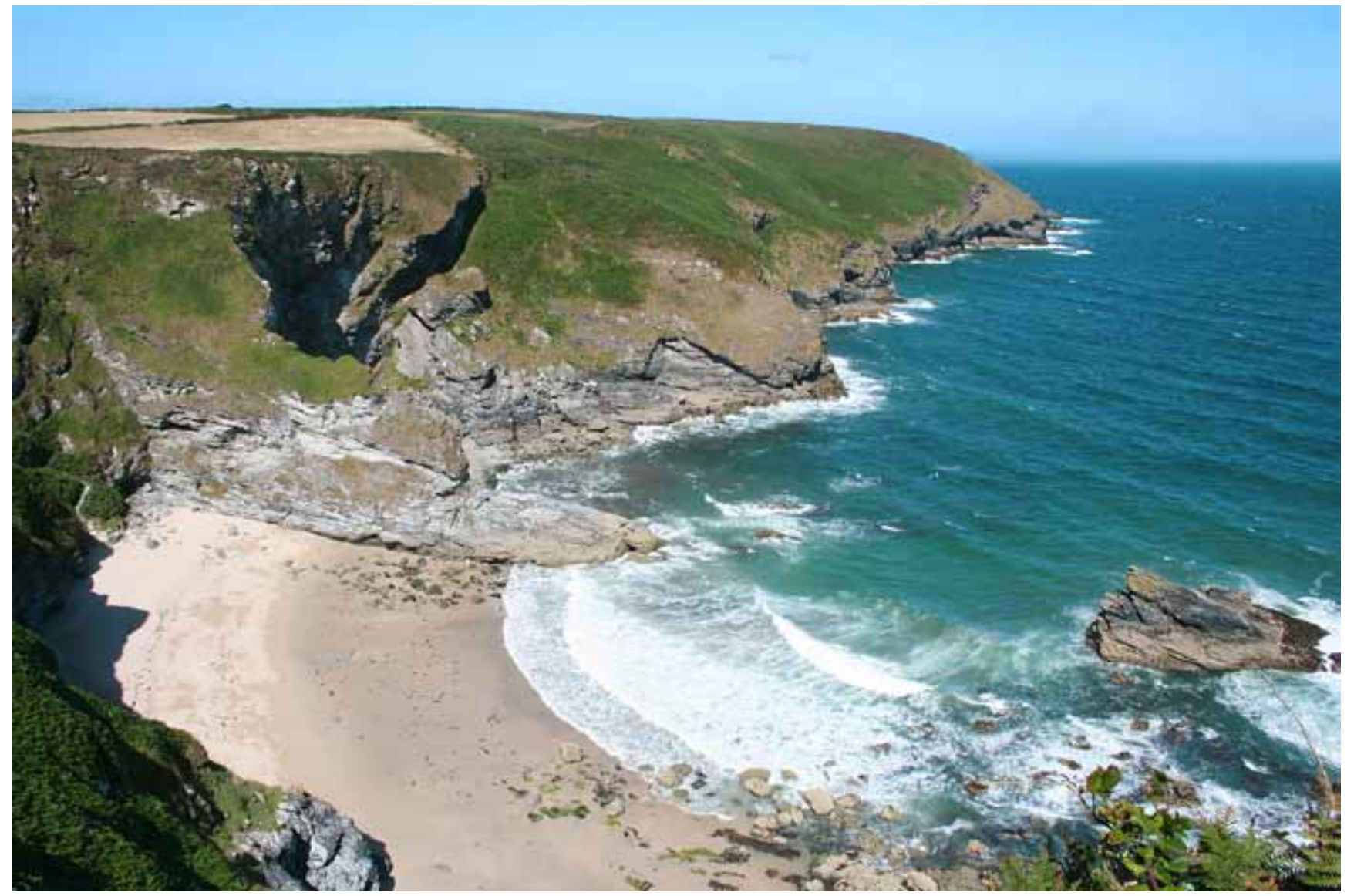

Fig. 1. Fishing Cove - one of many bays on the northern coast, phot. M.W. Lorenc • Fishing Cove - jedna z wielu zatok na północnym wybrzeżu, fot. M.W. Lorenc

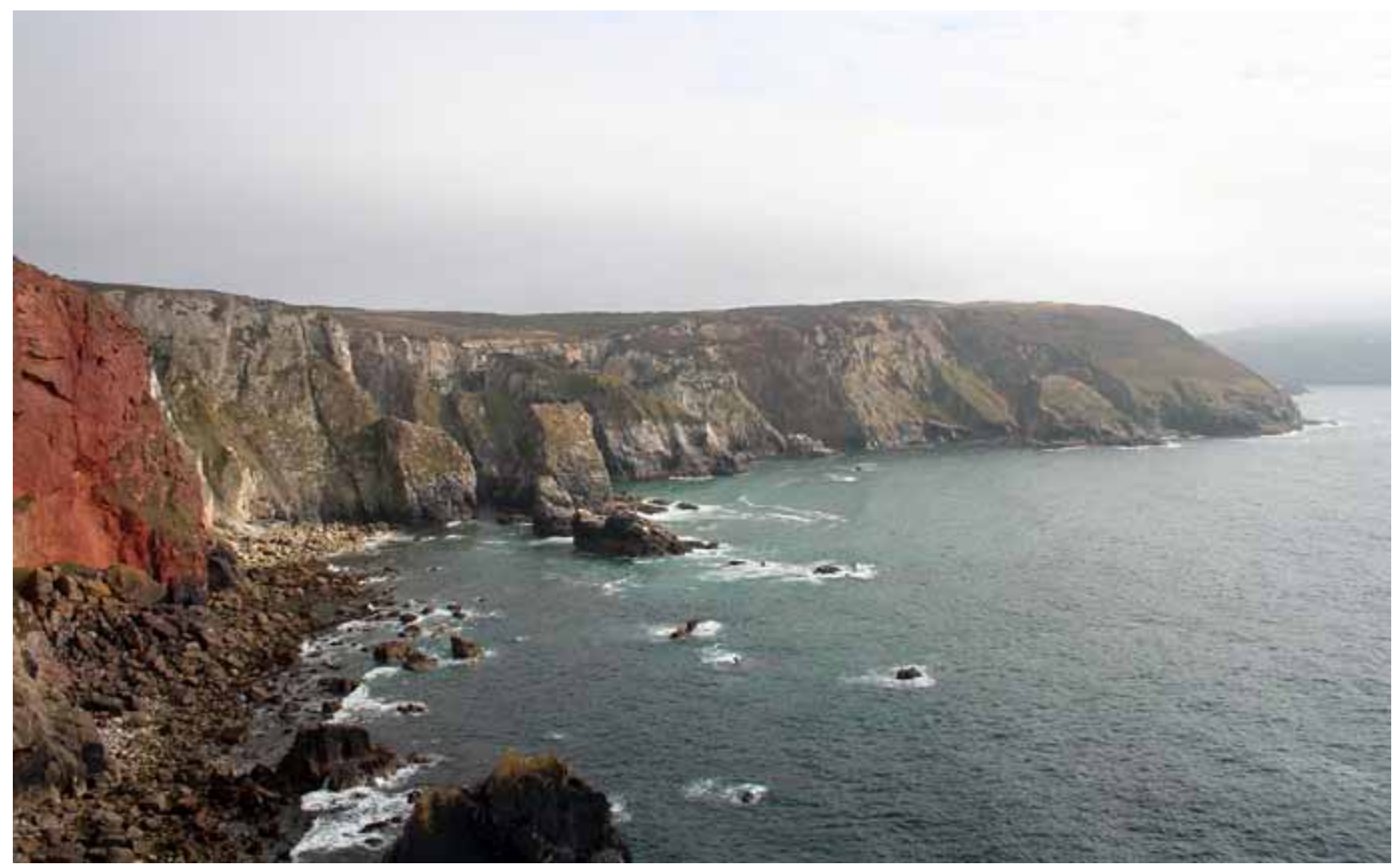

Fig. 2. Cligga Head - one of many cliffs on the northern coast, phot. M.W. Lorenc • Cligga Head - jeden z wielu klifów na północnym wybrzeżu, fot. M.W. Lorenc 


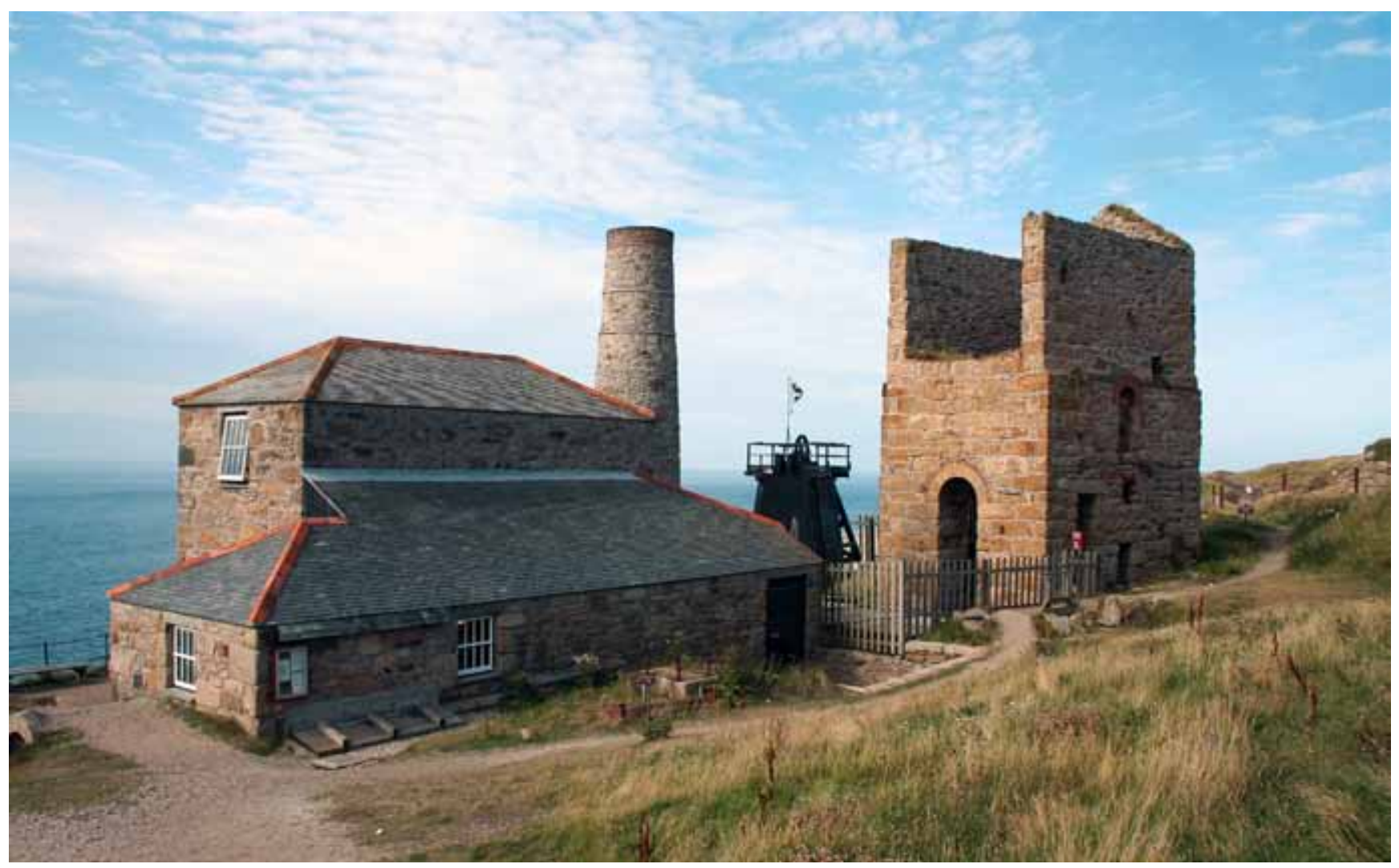

Fig. 3. The Levant Mine - a steam engine from the XIXth century still works in a partly reconstructed engine house, phot. M.W. Lorenc - Kopalnia Levant - w częściowo zrekonstruowanej maszynowni do dziś funkcjonuje XIX-wieczny silnik parowy, fot. M.W. Lorenc

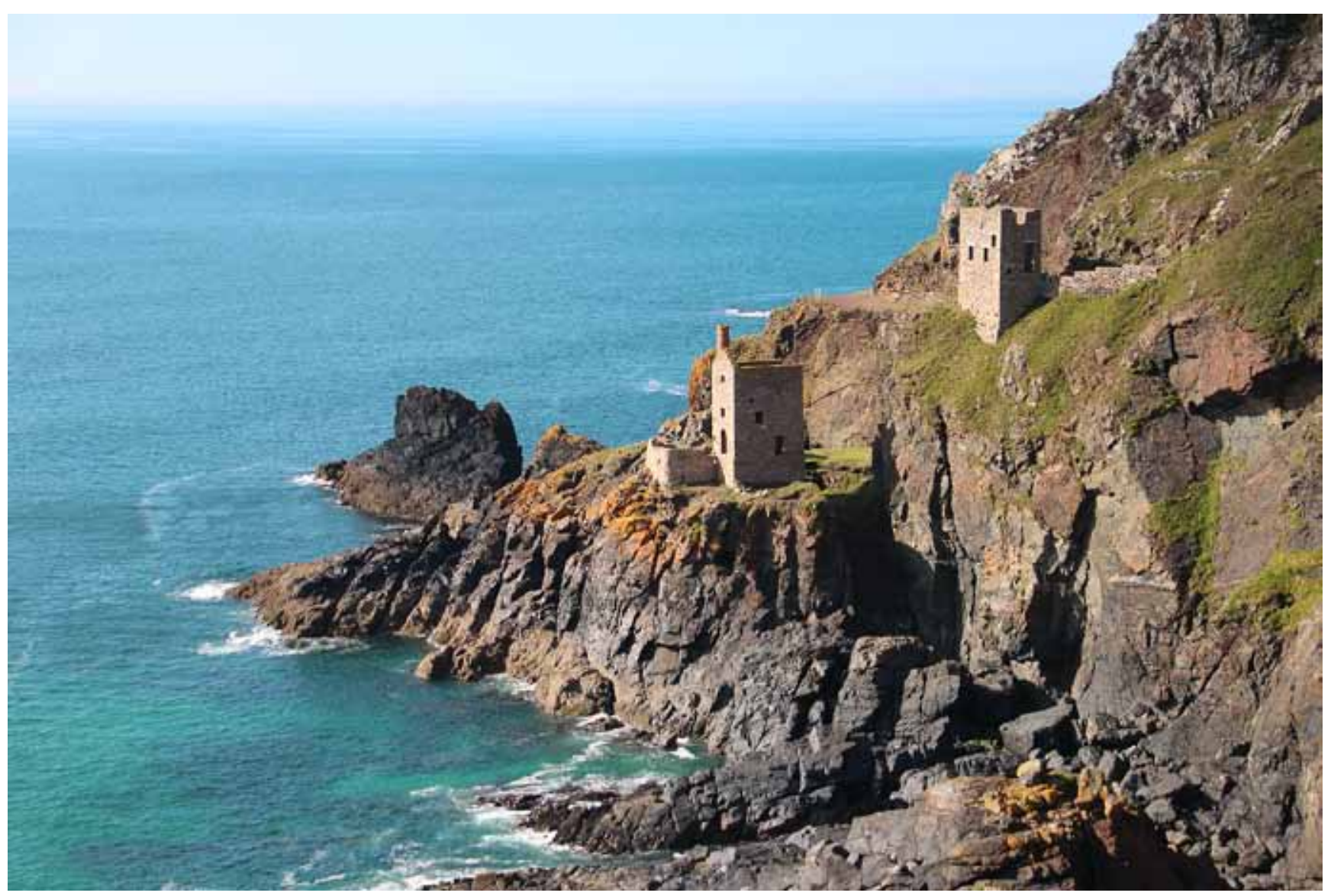

Fig. 4. The Botallack Mine - characteristic steam engine houses from the XIXth century, phot. M.W. Lorenc $\bullet$ Kopalnia Botallack - charakterystyczne w swojej formie XIX-wieczne maszynownie parowe, fot. M.W. Lorenc 
Perfect logistics, professional personnel and interesting interactive exhibitions cause that visiting this site is an unusual experience, not only aesthetic one but also cognitive and educational. The Eden Project is located in a very special place in relation to its history, geomorphology, landscape, flora and fauna. Along with its surroundings it creates a particularly interesting and diversified landscape.

The Eden Project is the largest natural complex established in a closed open pit originating from the XIXth century which was left after the extraction of kaolin near St. Austell (Fig. 5). Visitors are welcomed by extremely interesting architecture seen even from a distance. It consists of light-transmitting, semicircular domes hosting various ecosystems, completely different from the external environment. The structure of the domes consists of steel framework covered by plastic roofing in the shape of hexagonal panels (Fig. 6), which transmit sunrays and humidity, and can be entirely recycled (Smit, 2011). The project was invented by Tim Smit and designed by an outstanding British architect Nicholas Grimshaw. It took more than two years to complete the building, while searching for the proper location of the project itself has lasted just 5 years The ceremonial opening took place on March 17, 2001 and since then every year 1.2 million tourists have visited the Eden.

The project includes the Mediterranean biome, the rainforest biome, a unit called "the core" and the visitor centre. The external biome covers the area surrounding the buildings. The whole area hosts 18,000 plant species.

The rainforest biome presents a tropical humid climate; it is the world largest greenhouse of an impressive size: 240 meters long, 55 meters high and covering 1.3 hectare. Due to such size it was possible to locate there a fragment of jungle with a waterfall (Fig.7). Tropical climate was generated very realistically - temperature reaches even $+40^{\circ} \mathrm{C}$ while humidity amounts up to $80 \%$. This makes the longer stay in this compartment rather arduous. In order to ensure safety of visitors there are a few springs of drinking water and a "cool room" where the temperature is much lower.

The rainforest biome hosts the most exotic plants from Africa and South America, for example plantain (Musax paradisiaca), adansonia (Adansonia Digitala), papaya (Carica papaya), African quinine (Rauvolfia caffra), mother-in-law's tongue (Sansevieria trifasciata) or Swiss cheese (Monstera deliciosa) (Fig. 8).

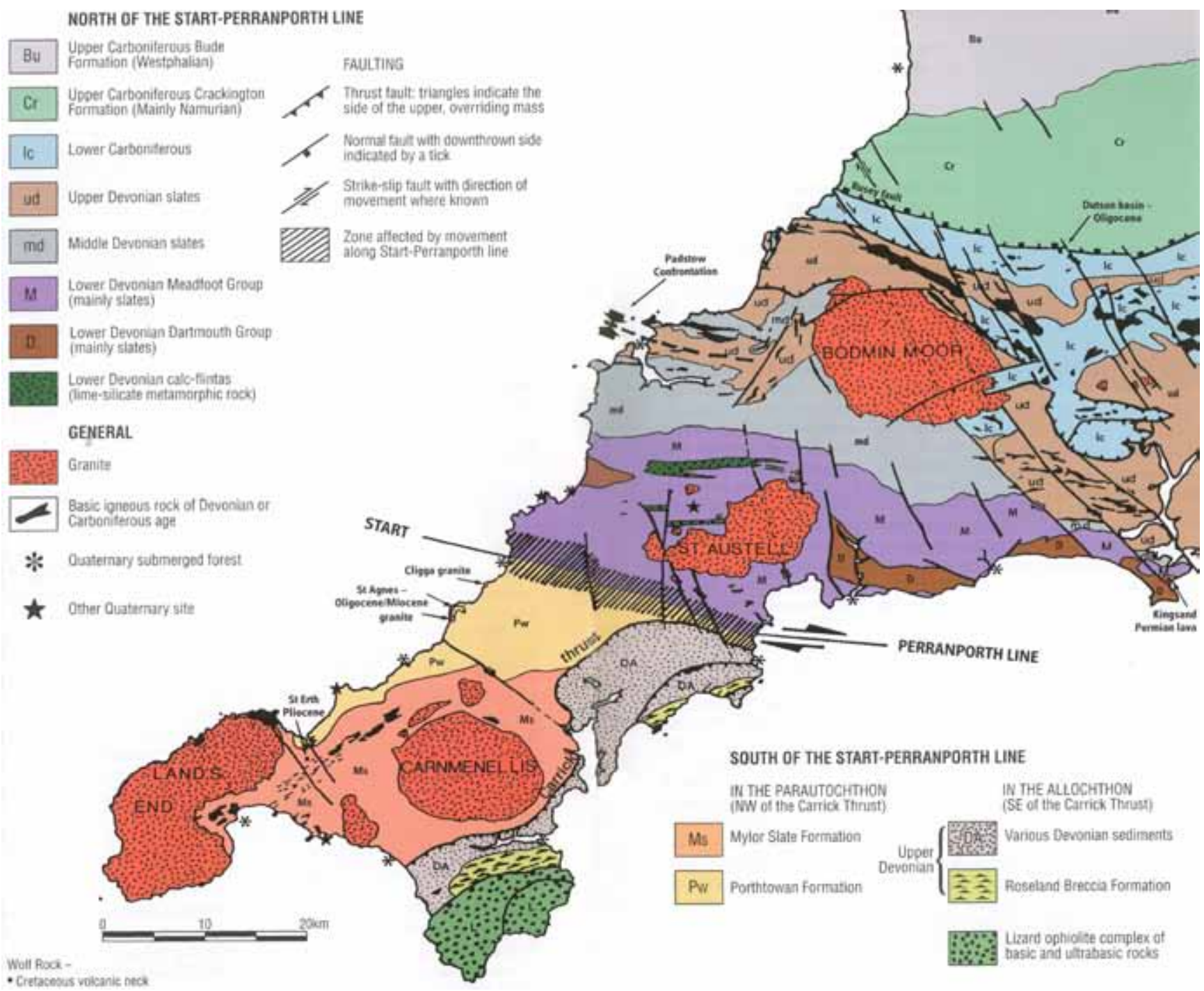

Fig. 5. Geological map of Cornwall (Bristow, 1996) • Mapa geologiczna Kornwalii (Bristow, 1996) 


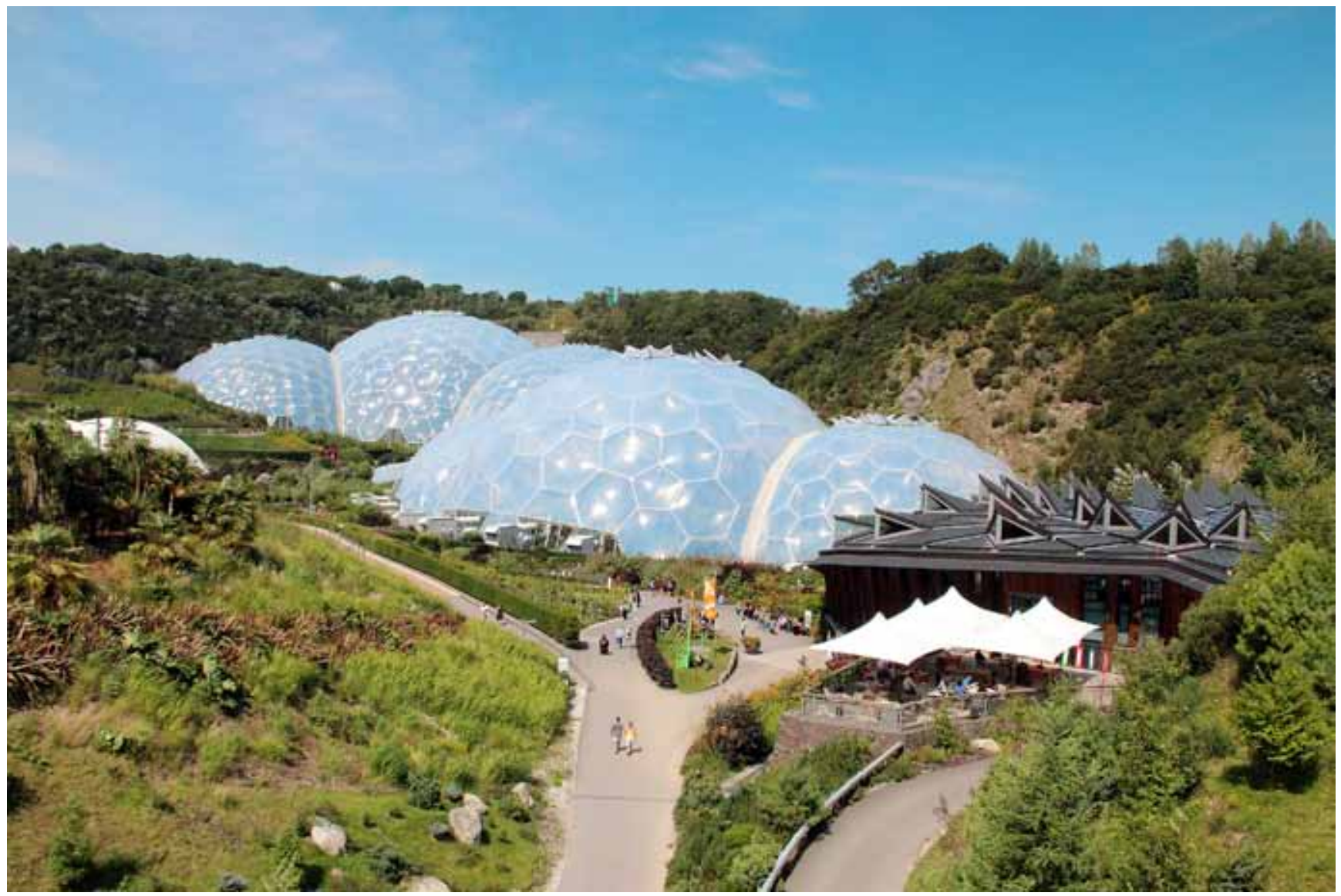

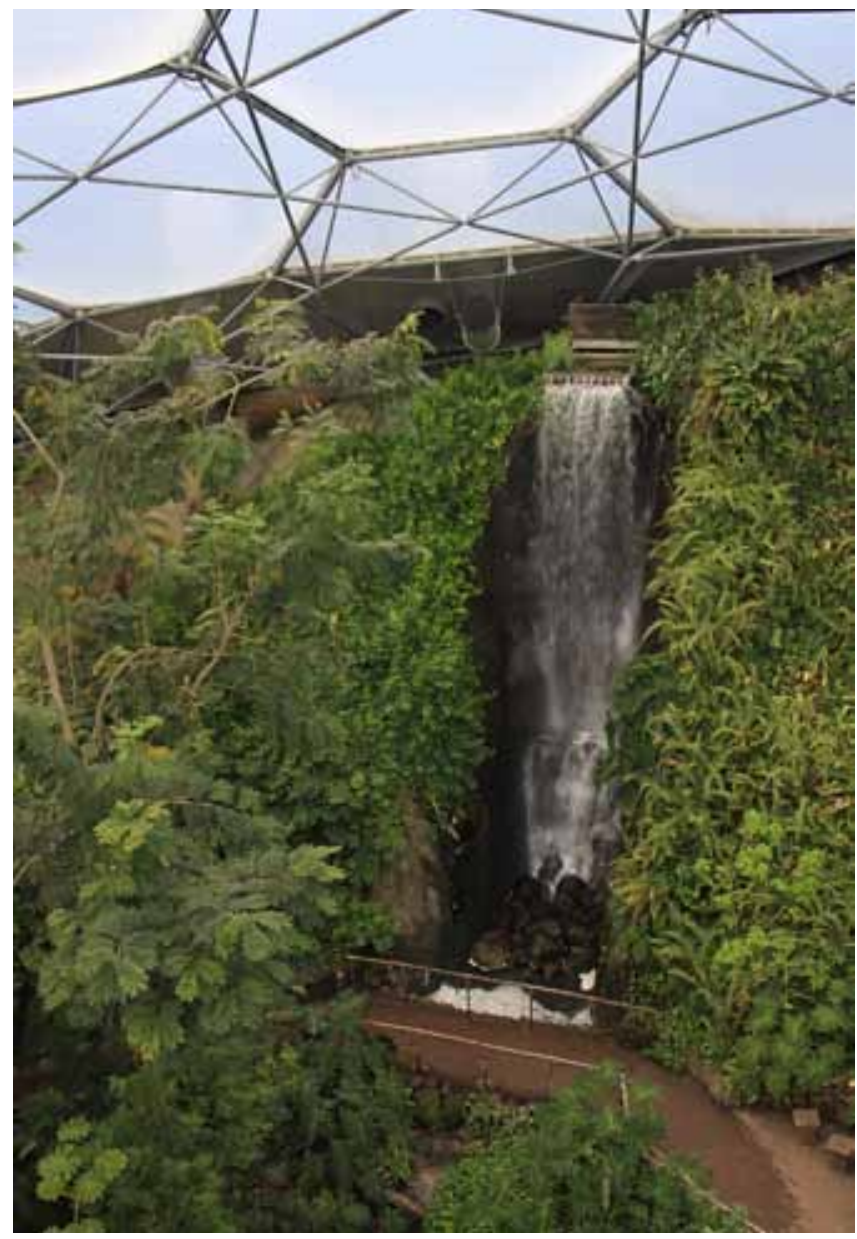

Fig. 6. View of the Eden Project, phot. E. Baczyńska • Widok na Projekt Eden, fot. E. Baczyńska

Fig. 7. View of the waterfall from a lookout platform located under the dome of the tropical biome, phot. E. Baczyńska. Widok na wodospad z tarasu widokowego znajdującego się pod dachem kopuły biomu tropikalnego, fot. E. Baczyńska

Despite the size of the plants, each species has its own information board containing the customary and Latin name, a short description and its usage. It is particularly practical and useful in the case of the youngest visitors because in many parts of the biome there are riddles and puzzles related to the world of plants. In this easy way children can learn, for example that the African kola tree (Cola acuminata) gives fruit used for the production of the world-famous drink, however, it takes 12 years before the tree starts to produce seeds. Most puzzles are interactive, which improves the contact of visitors with the surrounding nature.

A peculiar "pearl" of this biome is the biggest flower of Great Britain - titan arum (Amorphophallus titanum) which finally bloomed for the first time in June 2011. i.e., after 6 years. Vast swamps with mangroves forest give an impression of a real tropical jungle. The luxuriant vegetation is filled in with realistic copies of shelters of people living in that area. The first shelter is a Malaysian hut with the neighboring rice field. The aim was to express how much people of the Third World are dependent on agriculture and to present the average level of their life (Fig. 9). The second shelter made from palm leaves and bamboo shoots is commonly built by the victims of floods, landslides and sudden 
torrential rains, which each year strike Gambia in the Western Africa (Fig. 10). The purpose is to make visitors aware of how these people are exposed to the elements. This biome offers one more surprise - the whole object can be seen from a platform placed just under the dome, $50 \mathrm{~m}$ above the ground (Fig. 11).

In the Mediterranean biome visitors can take a walk among citrus or olive trees, grapevines and aromatic herbs located under the smaller dome (Fig. 12). It is 135 meters long abd covers some 0.6 hectare. It is connected with the rainforest biome with a special connector preventing the temperature drop. For plants growing in the dry zone of the Mediterranean climate the conditions mean hot summer and warm, rainy winter. This is the climate typical of South Africa, Southeast Australia, central part of Chile and California. Each of these regions is famous for growing juicy fruits, tasty wines and good crops. Sculptures of characters from Greek mythology remind of it and tell us about The Dionysia.

Plants living in these regions have adjusted to difficult water-soil conditions and generated special survival strategies. Various forms of leaves can be seen here - small green ones with hair as well as thorny or waxy leaves producing protective oils. As in the previous biome, all species are described in detail. Surprises for the youngest visitors are also available: competitions, hidden questions and interactive devices.

Fig. 8. View of the tropical biome, phot. E. Baczyńska - Widok na biom tropikalny, fot. E. Baczyńska
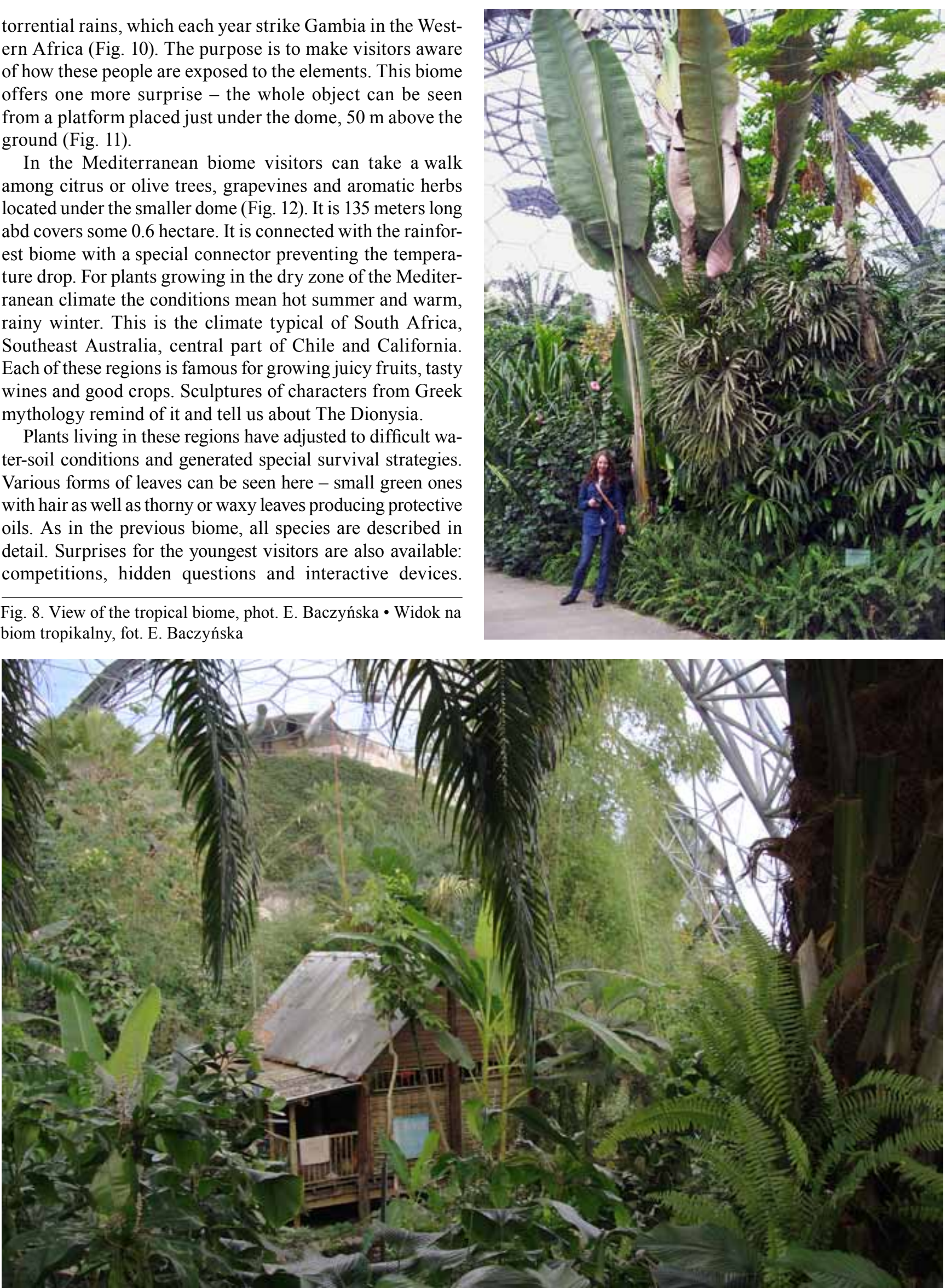

Fig. 9. View of the Malaysian hut surrounded by thick tropical forest, phot. E. Baczyńska • Widok na chatę malezyjską otoczoną przez gęsty las tropikalny, fot. E. Baczyńska 


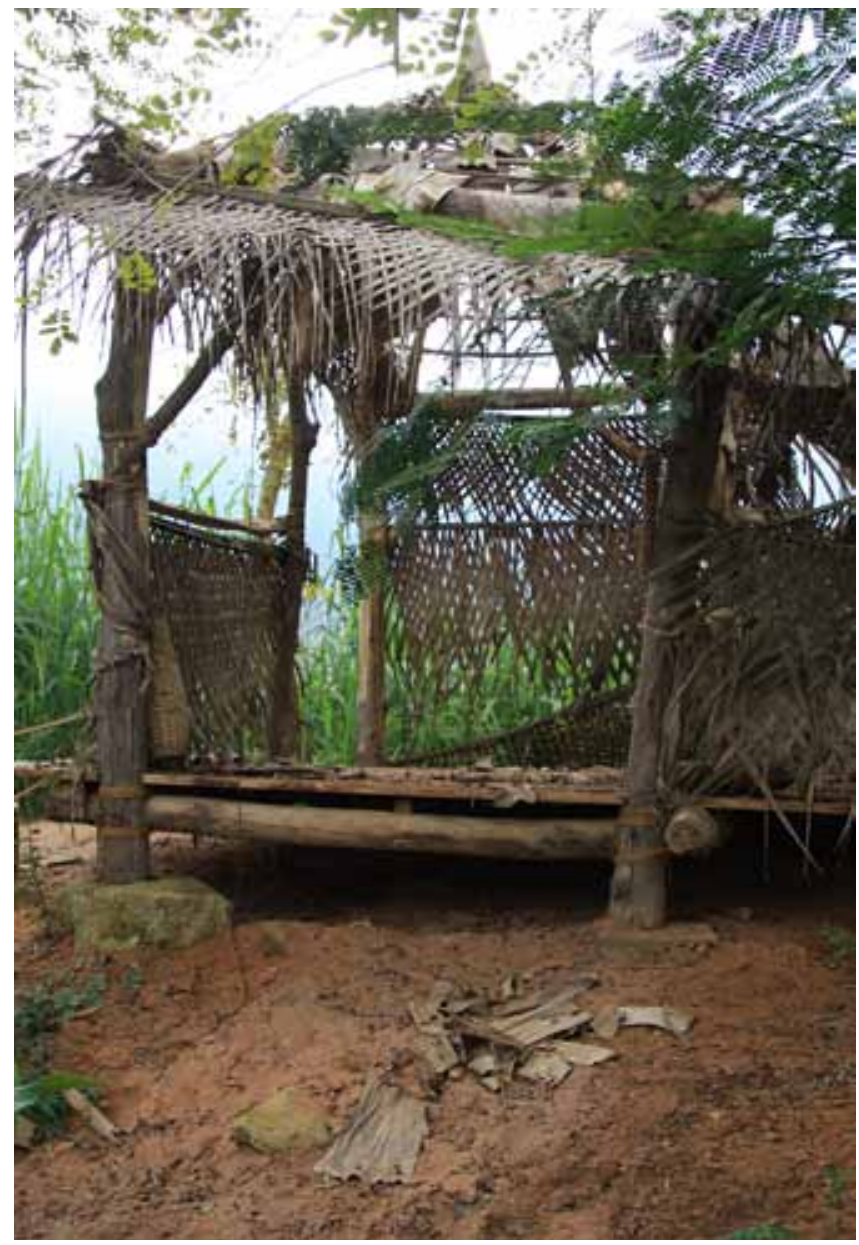

Everything is designed in a style characteristic for a particular region; therefore, it is not surprising that descriptions are often attached to the remains of Greek earthenware jugs, on walls of stairs of Spanish pergolas or on stones hidden among plants.

All these elements cause that almost every visitor is somehow a traveller and an explorer. It is possible here to move into a world known from fairy tales brought to mind by colours of lupines and poppy flowers. In this amazing collection of more than 1,000 species, including angiosperms (Angiospermae) from South Africa almost every visitor will find something interesting. The air humidity is not so high as in the tropical biome and it varies from 40 to $60 \%$ (although, depending on time of day and season, it may range from $40 \%$ to $99 \%$ ). The temperature is stabilized at $+25^{\circ} \mathrm{C}$ during the summer and at $+9^{\circ} \mathrm{C}$ during the winter.

The third biome joins all facilities and, at the same time, it is a separate compartment, which aim is to demonstrate to the visitors that only 10 years ago this area was a wasteland whereas today they have the possibility to admire the diversity of plant species. The sculptures or labels demonstrate how plants growing here were utilized by humans for medical purposes, as a fuel or food. Insects enlarged deliberately to a monstrous

Fig. 10. Shelter made of palm leaves and bamboo shoots, phot. E. Baczyńska • Schronienie $\mathrm{z}$ liści palmowych i pędów bambusa, fot. E. Baczyńska

Fig. 11. The Mediterranean biome. General view of the biome and of the lookout platform, phot. E. Baczyńska • Biom śródziemnomorski. Widok ogólny na biom i na platformę widokową, fot. E. Baczyńska

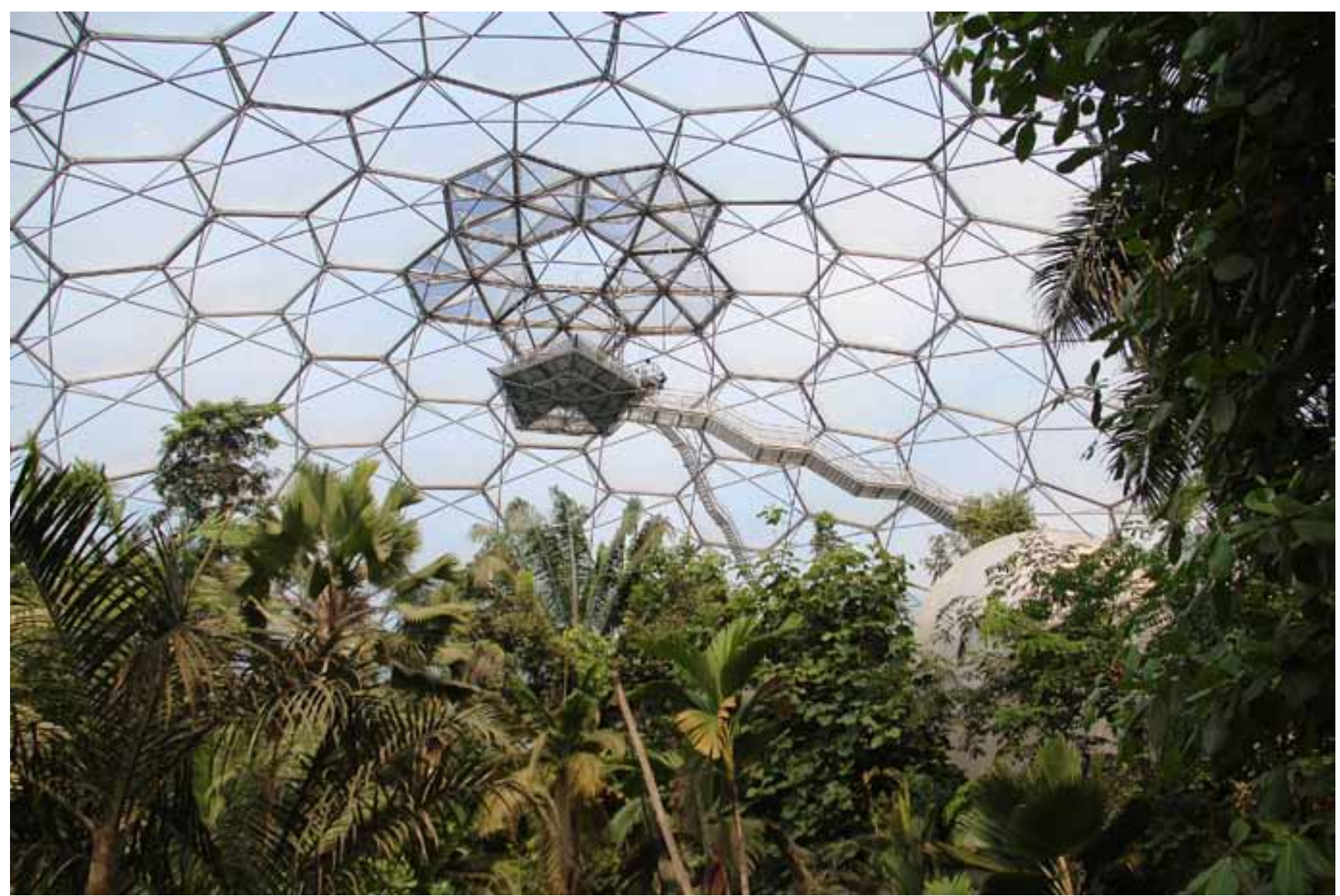


size teach children about their indispensable but often underestimated role in our life (Fig. 13). Elder guests will certainly comprehend a message expressed by a several meters high sculpture made entirely from waste (Fig. 14). Adequate numbers on information boards reveal the shocking truth about fatal influence of consumptionism on our planet and about a dramatic increase in electronic waste.

For those who wish to experience closer contact with the inanimate matter there is a climbing wall. It can be reached on foot or by special cars running every several minutes and carrying visitors on one side of the complex.

A supply of huge amounts of water and energy necessary to maintain such a huge number of plants in an artificial, man-made environment usually requires enormous expenses. However, the Eden Project is futureoriented as it has been designed in accordance with all the rules of environment protection and recycling. The initiators have taken advantage of opportunities provided by the British climate. If possible, a closed water circulation system is applied and rainwater is used for irrigation.

Fig. 12 Mandarine orange tree (Citrus reticulata), phot. E. Baczyńska $\bullet$ Drzewko mandarynkowe (Citrus reticulata), fot. E. Baczyńska Fig. 13. A huge bee placed in the external biome with information boards explaining the problem of a decreasing number of insects on the Earth and their role in our life, phot. E. Baczyńska • Gigantyczna pszczoła umiejscowiona w biomie zewnętrznym, dodatkowo opatrzona tablicami informującymi o problemie zmniejszania się liczby owadów na ziemi i ich znaczeniu dla życia człowieka, fot. E. Baczyńska
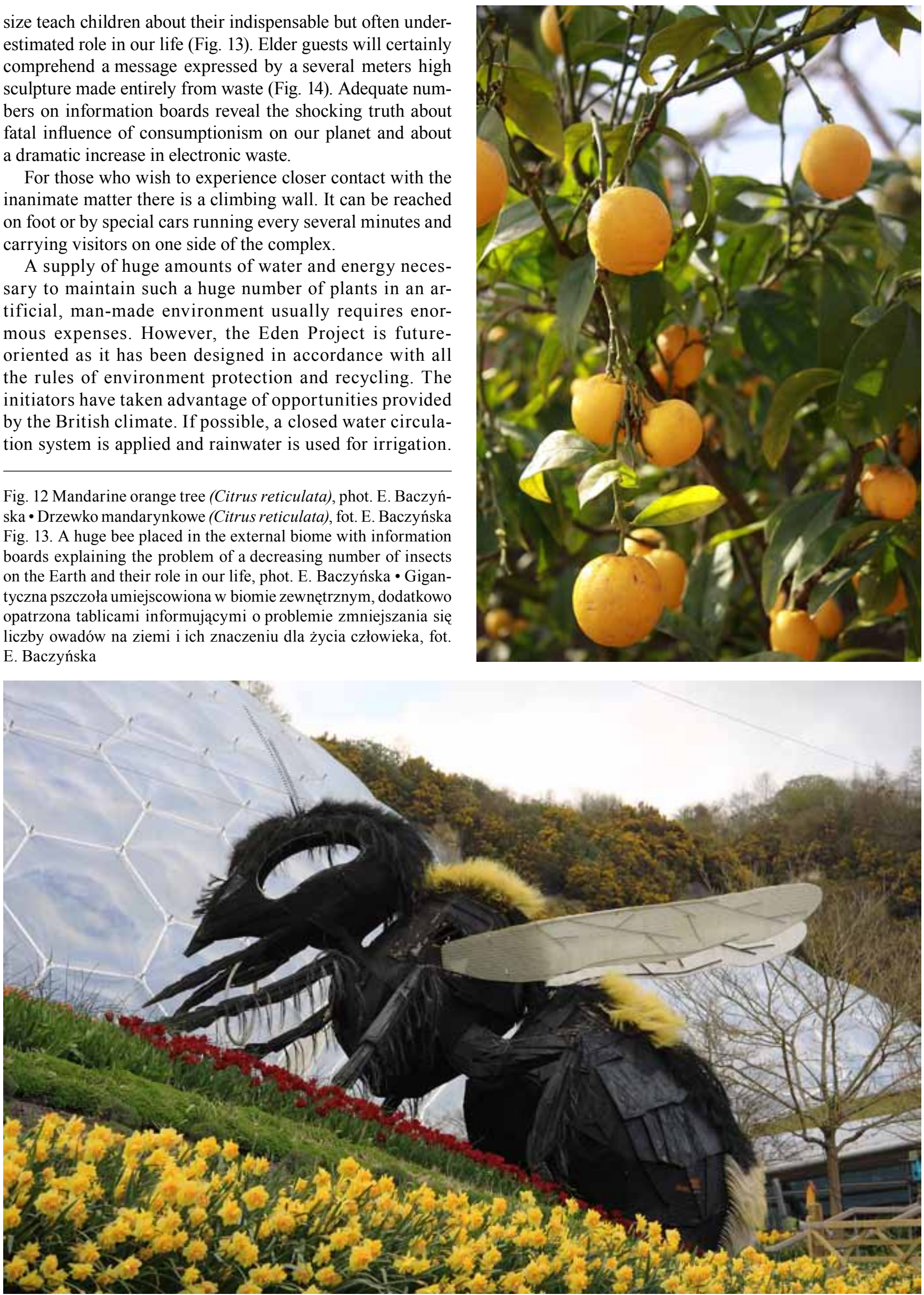
Additionally, an underground, automatic system of irrigation has been designed, which provides a proper level of soil moisture and, at the same time, it drains exccessive water. Electric energy produced by wind turbines is used for heating the facility (Smite 2011). Thanks to these technologies, the Eden Project is self-sufficient and open to visitors all year.

Due to such solutions, the Eden Project is not only a botanical garden with an impressive collection of plants. It is an enormous educational institution, which presents relations occurring in the nature. The aim of this venture is, above all, to teach the ecological aspects of life on Earth and to reveal the necessity of maintaining biodiversity. In order to emphasize this message, an additional part called "the Core" was built in 2007. Inside this centre visitors can learn out various aspects, such as evolution, ecosystems, plant resources, global warming. One of meaningful means of expression is a plant-machine presenting the dependence of the environment, including our existence, on plants. A few times a year

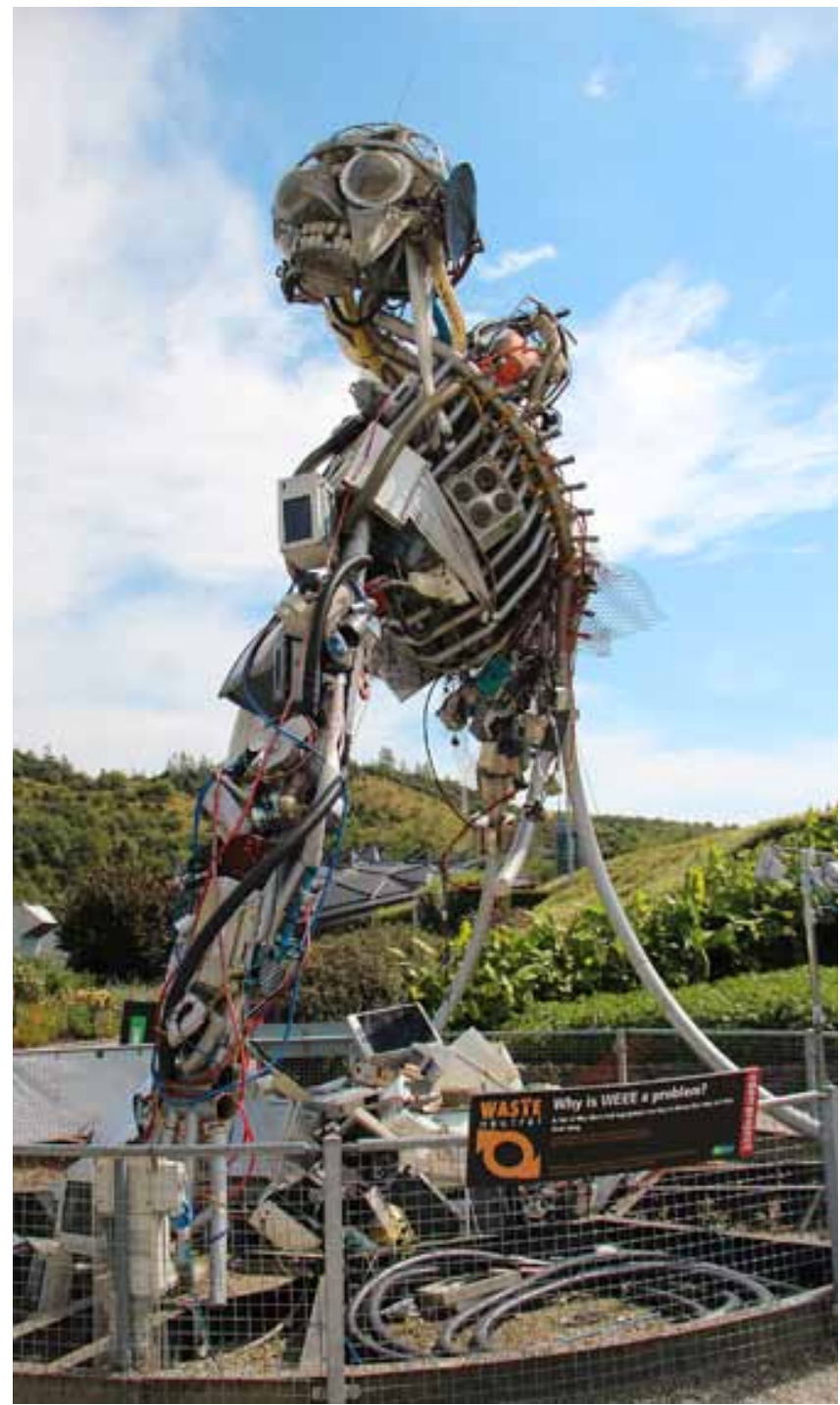

Fig. 14. Sculpture built entirely from wastes with information boards related to the problem of littering the planet, phot. E. Baczyńska - Rzeźba wykonana w całości z odpadów, dodatkowo opatrzona tablicami informującymi o problemie zaśmiecania planety, fot. E. Baczyńska „the core” changes into a place of special events. One of them was a presentation of possibilities of light illuminations based on optical fibre technics (Fig. 15). Moreover, visitors can recognize how to collect and use rainwater or acquire energy from solar panels. They also have a chance to discover the history of the whole project (op. cit.).

The variety of plants is not the only attraction offered by the project. Depending on the season of the year, many events are organized there - various meetings, concerts, thematic games, a skating rink. The project deserves to be named "the work of the XXIst century" as it is entirely accessible for disabled visitors. From doors equipped with a photocell, all vehicles, elevators to the lack of doorsteps - everything is user-friendly.

Being first of all an educational institution, the Eden Project is supposed to make visitors aware of ecological aspects of life on the Earth. It is achieved by a number of individual and group courses. Science here is not only related to fun and reserved for the youngest guests. It is also a good experience for adults who want to try something new or to develop their hobby related for example to plant cultivation and learning their characteristics.

Regardless of whether you are an amateur or a gardening professional, the courses organised here are a perfect way of combining practical knowledge and skills. Moreover, those who wish to develop their own business will find here support programs, which help to recognize the issues of environment protection and to use them in their own projects. Decreasing the emission of carbon dioxide by enterprises may be an example. The Eden Project also takes part in a program which introduces so-called social and environmental "good practice" in mining and, at the same time, it sets the best example of its application. Educational programs are designed for schools, teachers, parents who look for new methods of making young people involved and aware of significant processes occurring on our planet.

Visitors have also the possibility to take a guided tour in each biome. Guides inform about the huge role of rainforest and teach how it keeps our planet alive and how can we help to protect it. They present curiosities of cultivation particular plants, tell about ways of living in different climatic zones and present local huts, facilities and food.

The schedule of events and courses changes with the seasons of the year. Methods of their presentation depend on atmospheric conditions, too. Multimedia displays in the open air are organised when the weather is favourable, together with courses of mountain climbing, various concerts, stories told live and, in winter, even a skating rink. There is a possibility to organise here parties for children such as birthday and for adults, for example wedding receptions in an unusual scenery.

The Eden Project is a very large object and, apart from biomes, it includes a huge area of specialised outdoor gardens. The time of sightseeing is unlimited and it only depends on interests and fitness of the visitors.

In the neighbourhood of the Eden Project there is a large parking lot divided into a few levels which are marked with pictures and names of fruits in order to make finding a car easier. 


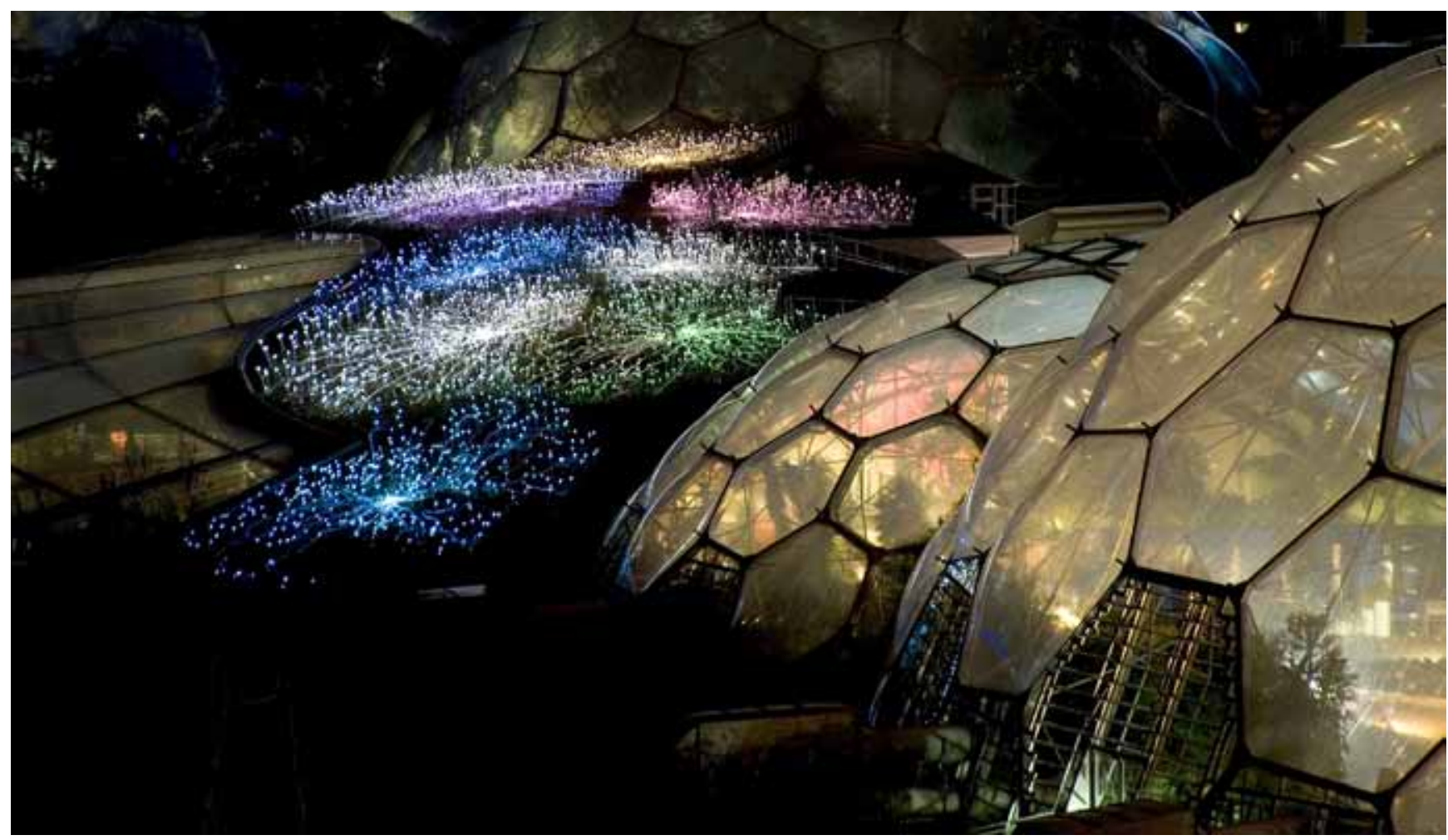

Fig. 15. Illumination of the Eden Project designed by Bruce Munro, phot. M. Pickthall • Iluminacja Projektu Eden autorstwa Bruce Munro, fot. M. Pickthall

From here to the bus stop located at the entrance the visitors can take internal communication buses. The routes are marked with corresponding fruit names.

\section{Final remarks}

The Eden Project is a huge venture and the idea of utilizing a closed mine excavation certainly deserves appreciation. Moreover, by combining many interesting functions, this project is a perfect educational and entertaining facility. It can be truly named "a living project" because it changes constantly, never stays the same. With each new season it manages to surprise the visitors. A breath-taking performance, which consists of over 10,000 plants and attracts tourists with its colours and aroma all the year, has been enriched with the sound of rushing water, bird songs and wind. Everything here contributes to a whole designed in order to stimulate not only one but all our senses. Additionally, visitors can have a meal in the neighboring restaurants, cafes and snack bars, where they can try such specialities of local cuisine like warm pasties, handmade croissants, fresh, seasonal salads, or freshly backed bread, all prepared only from ecological ingredients.

The entire touristic and logistic systems deserve credit because they meet the various requirements of visitors who have different likes and dislikes, and different sensitivity.

The Eden Project, apart from offering a huge variety of flora and the diversity of entertainment, is above all an educational centre because it presents our strong dependence on the plants. If we do not take care of plants, which are the key components for the development of our planet, we will lead to self-destruction. The largest biome demonstrates it clearly because a fragment of the rainforest of this size is irretrievably cut down every 10 seconds. This knowledge enables us to realize that a negative influence on our planet results in condemning ourselves and that is why the educational role of this facility is so valuable. $\square$

\section{Streszczenie}

\section{Projekt Eden - osobliwość Półwyspu Kornwalijskiego}

\section{Elżbieta Baczyńska, Marek W. Lorenc}

\section{Wstęp}

Półwysep Kornwalijski leży w południowo-zachodniej części Wielkiej Brytanii, pomiędzy Morzem Celtyckim i Kanałem Bristolskim na północy, a kanałem La Manche na po- łudniu. Jego wybrzeże charakteryzuje się dużym zróżnicowaniem form riasowych; wysokie klify i głęboko wcięte w ląd zatoki są niezwykle malownicze i często odwiedzane przez turystów (Fig. 1 i 2). Półwysep leży w strefie klimatu umiarkowanego morskiego, co czyni go najcieplejszym rejonem Wysp Brytyjskich. Dzięki średniej rocznej temperaturze na poziomie $10-12^{\circ} \mathrm{C}$, miejsce to obfituje w parki oraz ogrody obsadzone egzotyczną roślinnością. Bardzo charakterystycznym dla Kornwalii krajobrazem są rozległe wrzosowiska i torfowiska, przy zupełnym braku terenów zalesionych. 
Dawniej podstawę lokalnej gospodarki stanowiło górnictwo, a dokładniej wydobycie cyny, mające na tym terenie niezwykle długą i złożoną historię. Pierwsze ślady wydobycia rud cyny datuje się tu na około 3500 lat p.n.e. Szczyt rozwoju górnictwa cyny przypada na XIX wiek, na co niebagatelny wpływ miało wynalezienie silnika parowego. Warto podkreślić, że jeden z pierwszych silników parowych Watta znalazł zastosowanie właśnie w jednej z kornwalijskich kopalń (Fig. 3). Definitywna likwidacja przemysłu wydobywczego i zamknięcie ostatnich zakładów górniczych miało miejsce w 1998 roku (Schwartz 2006, Schwartz, Lorenc 2011). Wszędzie tam spotyka się charakterystyczne, kornwalijskie budynki, mieszczące potężne silniki parowe, odpowiedzialne za odwadnianie i transport pionowy w kopalniach (Lorenc, Cocks 2008) (Fig. 4).

Obecnie Kornwalia to głównie region turystyczny, a turystyka stanowi podstawę tutejszej gospodarki. Pozostała część półwyspu to obszar rolniczo-hodowlany, z rozległymi pastwiskami. Małe miasteczka, zatoki czy klify przyciągają rokrocznie wielu turystów. Jednym z takich miejsc, oferującym dodatkowo ciekawą formę rozrywki, jest właśnie Projekt Eden, tak licznie odwiedzany przez turystów z całego niemal świata.

\section{Budowa geologiczna}

Budowa geologiczna tej części Wielkiej Brytanii jest dość urozmaicona, aczkolwiek większość skał odsłaniających się na powierzchni to utwory osadowe dewonu (stratotyp i nazwa tego okresu pochodzi właśnie od pobliskiego hrabstwa Devon), z podrzędnym udziałem sedymentów karbońskich i licznymi intruzjami waryscyjskich granitoidów z przełomu karbonu i permu (Fig. 5).

Pod względem strukturalnym Półwysep Kornwalijski podzielony jest na dwie części, a granicę między nimi stanowi wielka strefa ścinania, przebiegająca prawie równoleżnikowo około $10 \mathrm{~km}$ na południe od linii Newquay - St. Austell, zwana Linią Start-Perranporth (SPL). Na północ od niej występują dewońskie łupki i mułowce z wkładkami wapieni, które miejscami, na skutek metamorfizmu regionalnego, zostały przekształcone w marmury. Więcej marmurów, wraz ze skałami wapniowo-krzemianowymi, przeobrażonymi na skutek metamorfizmu termicznego, znajduje się w strefach kontaktowych z granitoidami (Bristow, 1996).

Na południe od linii SPL występują zupełnie inne utwory, choć również wieku dewońskiego. Są to formacje o charakterze parautochtonicznym, związane $\mathrm{z}$ istnieniem aktywnej strefy kolizyjnej, reprezentowane przez szare łupki, piaskowce i mułowce pochodzenia turbidytowego, którym towarzyszą liczne brekcje osadowe, powstałe na skutek podmorskich osuwisk. Formacje allochtoniczne stanowią utwory płaszczowinowe, nasunięte z południowego wschodu. Ich najstarszą część tworzy olistolit ordowickiego kwarcytu wraz z lawami poduszkowymi, zaś część młodszą - piaskowce i towarzyszące im osady turbidytowe oraz wapienie z krzemieniami. Jednostką odrębnego typu jest Kompleks Lizard, będący charakterystycznym dla takiego reżimu tektonicznego ofiolitem. Występują tu tak charakterystyczne skały magmowe jak perydotyty płaszczowego pochodzenia, kumulaty o składzie dunitu, a także gabra oraz towarzyszące im rozległe dajki zasadowe i lawy poduszkowe. W skałach tych spotyka się porwaki wapieni, kwarcytów, czertów oraz okruchy wulkanitów stanowiących dawne dno oceaniczne (Bristow, 1996).

Po obu stronach linii tektonicznej SPL osadowym skałom dewońskim towarzyszą liczne skały wulkaniczne, których chemizm wykazuje typową charakterystykę MORB (Mid-Ocean Ridge Basalts). Również po obu stronach wspomnianej linii tektonicznej skały wszystkich formacji poprzecinane są licznymi intruzjami waryscyjskich granitów, otoczonych dość rozległymi strefami metamorfizmu kontaktowego, którego produktem są bardzo powszechnie występujące hornfelsy. Skład mineralny, a tym samym chemiczny tych skał nie jest jednorodny; obok granitów biotytowych z dużymi, miejscami kierunkowo ułożonymi kryształami skalenia potasowego, występują też granity dwułyszczykowe, granity $\mathrm{z}$ turmalinem oraz leukogranity (Lorenc, 1994).

Z ekonomicznego punktu widzenia bardzo ważne były procesy mineralizacji, które doprowadziły do powstania w samym granicie, jak i w skałach jego osłony bogatych złóż, przede wszystkim cyny i miedzi, eksploatowanych w Kornwalii przez ponad trzy tysiące lat. Drugim bogactwem Kornwalii był biały kaolin, tworzący się na skutek wietrzeniowego rozkładu jednej z odmian granitu, a będący źródłem wysokiej jakości glinki używanej do produkcji porcelany. Szczególnie bogate złoża kaolinu na terenie Kornwalii związane są z intruzją jednego z młodszych granitów, znajdującą się na północ od miasta St. Austell.

\section{Atrakcje Projektu Eden}

Najpowszechniej stosowanym dotychczas sposobem zagospodarowania nieczynnych kamieniołomów jest kierunek leśny oraz wodny, jednakże zmieniające się zapotrzebowanie społeczno-gospodarcze sprawiło, iż poszukiwane są wciąż nowe rozwiązania (Krawczyk, Lorenc, 2010).

W przypadku surowców skalnych obszary poeksploatacyjne coraz częściej adaptowane są na parki rozrywki, amfiteatry, rezerwaty przyrody czy ośrodki poświęcone edukacji. Termin ,adaptacja” oznacza w tym przypadku przystosowanie terenu po eksploatacji do pełnienia nowej funkcji, przy czym pojęcie adaptacji jest terminem uniwersalnym, ponieważ łączy w sobie pojęcia rekultywacji oraz zagospodarowania (Pietrzyk-Sokulska, 2005, Skoczylas, 2008).

Projekt Eden jest największym na świecie kompleksem przyrodniczym, utworzonym w nieczynnym od XIX wieku wyrobisku po odkrywkowej eksploatacji kaolinu w okolicach St. Austell (Fig. 5). Już z daleka odwiedzających wita ciekawa architektura. Składają się na nią przepuszczające światło półkuliste kopuły, pod którymi znajdują się odmienne względem siebie i względem środowiska zewnętrznego ekosystemy. Konstrukcja kopuł składa się ze stalowych szkieletów w kształcie sześciokątnych paneli pokrytych plastykowym poszyciem (Fig. 6). Mają one zdolność przepuszczania promieni świetlnych i wilgoci oraz w całości nadają się do recyclingu (Smit, 2011). Twórcą pomysłu jest Tim Smit, natomiast projekt wykonał wybitny brytyjski architekt Nicholas Grimshaw, a odpowiedniego na lokalizację miejsca szukano przez 5 lat. 
Eden Project - the Cornwall Peninsula peculiarity

Na całość projektu składają się: biom śródziemnomorski, biom lasu deszczowego, a także obiekt zwany Jądrem oraz budynek centrum turystycznego. Okalający teren, na którym znajdują się wszystkie budynki, to biom zewnętrzny. Całość zawiera nasadzenia 18 tysięcy gatunków roślin.

Biom lasu deszczowego odzwierciedla klimat tropikalny, wilgotny. Przy imponujących wymiarach: 240 m długości, 55 m wysokości i powierzchni 1,3 ha stanowi on największą szklarnię świata. Tak znaczne rozmiary obiektu pozwalają na swobodne pomieszczenie wewnątrz niego dżungli wraz z wodospadem (Fig. 7). Panujące tam tropikalne warunki zostały tak wiernie odtworzone, że przebywanie w nich przez dłuższy czas może być uciążliwe ze względu na temperaturę osiągającą nawet $+40^{\circ} \mathrm{C}$, przy wilgotności powietrza około $80 \%$. Tutaj znajdują się najbardziej egzotyczne rośliny Afryki i Ameryki Południowej (Fig. 8).

Rozległe bagna wraz z lasem namorzynowym dają namiastkę prawdziwej tropikalnej dżungli, natomiast uzupełnieniem bujnej roślinności są wiernie odtworzone schronienia zamieszkujących na jej terenie ludzi. Jednym $\mathrm{z}$ nich jest malezyjska chata z sąsiadującym polem ryżowym, której założeniem było ukazanie jak bardzo ludność krajów Trzeciego Świata jest zależna od rolnictwa oraz przedstawienie przeciętnego standardu życia w tym regionie (Fig. 9). Drugim jest schronienie $\mathrm{z}$ liści palmowych i pędów bambusa, które budują sobie ludzie w razie wystąpienia ekstremalnych zjawisk naturalnych, nawiedzających rokrocznie na przykład Gambię w zachodniej Afryce (Fig. 10). Biom ten skrywa jeszcze jedną niespodziankę, bowiem cały obiekt można podziwiać z platformy umieszczonej tuż pod sklepieniem kopuły, a znajdującej się na wysokości około $50 \mathrm{~m}$ nad ziemią (Fig. 11).

Spacer pośród drzew cytrusowych, oliwnych czy winorośli oraz aromatycznych ziół można odbyć w biomie śródziemnomorskim, znajdującym się pod mniejszą kopułą (Fig. 12). Rozciąga się on na długości $135 \mathrm{~m}$, ma powierzchnię 0,6 ha $i$ jest połączony $z$ biomem lasu deszczowego specjalnym łącznikiem, którego zadaniem jest ograniczenie spadku temperatury. Dla rosnących tu roślin strefy suchej klimatu śródziemnomorskiego oznacza to gorące lato oraz deszczową, ciepłą zimę. Rośliny zamieszkujące tę strefę przystosowały się do życia w trudnych warunkach wodno-glebowych, wypracowując odpowiednie dla danego miejsca metody przetrwania. Wszystko to sprawia, że niemal każdy zwiedzający jest niejako podróżnikiem i odkrywcą jednocześnie. Można się tu przenieść w świat znany z baśniowych opowieści, który jest przywoływany barwami kolorowych łubinów czy maków. Zbiór ponad tysiąca gatunków roślin sprawia, że każdy odwiedzający może znaleźć coś ciekawego dla siebie. Wilgotność powietrza nie jest tu tak wysoka jak w biomie tropikalnym, utrzymując się w granicach 40-60\% (aczkolwiek sporadycznie, w zależności od pory dnia i roku, może wzrosnąć nawet do 99\%). Temperatura jest utrzymywana na poziomie $+25^{\circ} \mathrm{C}$ w okresie letnim oraz $+9^{\circ} \mathrm{C} \mathrm{w}$ okresie zimowym.

Trzeci biom spójnie łączy wszystkie obiekty, będąc jednocześnie osobną częścią, mającą na celu uzmysłowienie zwiedzającym, że jeszcze 10 lat temu teren ten był jałowy, zaś dziś można na nim podziwiać mnogość gatunków. Znaj- dujące się tu rośliny, za pomocą rzeźb lub oznaczeń, ukazują jak ludzie korzystają z ich dobrodziejstwa w celach medycznych, jako paliwa czy też pożywienia. Celowo powiększone do monstrualnych rozmiarów owady mając za zadanie nauczyć dzieci, że w naszym życiu ich rola, choć często niedoceniana, jest jednak niezbędna. (Fig. 13). Do starszych odbiorców dotrze z pewnością przekaz, który niesie ze sobą kilkumetrowej wysokości rzeźba, w całości wykonana z odpadów (Fig. 14). Odpowiednie liczby na tablicach informacyjnych ukazują prawdę o zgubnym dla naszej planety wpływie konsumpcjonizmu oraz o dramatycznym wzroście ilości odpadów elektronicznych.

Zapewnienie ogromnych ilości wody oraz energii, potrzebnych do utrzymania tak wielu roślin w środowisku sztucznie stworzonym przez człowieka, musi się zazwyczaj wiązać z ogromnymi nakładami finansowymi. W tym przypadku pomysłodawcy wykorzystali możliwości, które daje brytyjski klimat, w związku z czym utrzymywany jest zamknięty obieg wody, a do nawadniania stosuje się wodę deszczową. Do ogrzewania wykorzystuje się energię elektryczną, która produkowana jest przez turbiny wiatrowe Kornwalii (Smit, 2011). Dzięki zastosowaniu tych technologii Projekt Eden jest samowystarczalny, a przez to dostępny dla zwiedzających przez cały rok.

Zastosowane rozwiązania powodują, iż Projekt Eden nie jest tylko ogrodem botanicznym, posiadającym pokaźny zbiór roślin. Jest to olbrzymia instytucja edukacyjna, która odzwierciedla relacje zachodzące w naturze. W 2007 roku została dobudowana dodatkowa część zwana „Jądrem”, w którym zwiedzający mogą przyjrzeć się różnym aspektom, począwszy od ewolucji, poprzez ekosystemy, zasoby roślin, na zagadnieniach dotyczących globalnego ocieplenia skończywszy. Wymownym środkiem przekazu jest między innymi roślina-maszyna, ukazująca zależność środowiska - a tym samym naszej egzystencji - od roślin. Kilka razy do roku Jądro zamienia się w miejsce imprez okolicznościowych. Jedną z nich była prezentacja możliwości iluminacji świetlnych oparta na technice światłowodowej (Fig. 15).

Jako instytucja przede wszystkim edukacyjna Projekt Eden ma za zadanie uczulić odbiorcę na aspekty ekologiczne, związane z życiem na Ziemi. Realizuje się to dzięki wielu indywidualnym i grupowym kursom. Nauka nie jest tu związana wyłącznie $\mathrm{z}$ zabawą i zarezerwowana tylko dla najmłodszych. Jest to miejsce równie dobre dla osób dorosłych, chcących spróbować czegoś nowego lub rozwijać swoje hobby związane np. z uprawą roślin i poznawaniem ich właściwości. Niezależnie od tego czy jest się amatorem, czy osobą związaną zawodowo z ogrodnictwem, prowadzone tu kursy są doskonałym sposobem na połączenie praktycznej wiedzy z umiejętnościami. Także dla ludzi chcących rozwijać swoją działalność gospodarczą Projekt Eden oferuje programy wsparcia, pomagające przedsiębiorcom w poruszaniu się w zagadnieniach ochrony środowiska i wykorzystywaniu ich w swoich projektach. Przykładem może być m.in. obniżanie emisji dwutlenku węgla przez przedsiębiorstwa. Eden bierze także udział w programie związanym z wprowadzaniem społecznych i środowiskowych tzw. ,dobrych praktyk” w górnictwie, samemu stanowiąc najlepszy tego przykład. 
Programy edukacyjne konstruowane są z myślą o szkołach, nauczycielach, a także o rodzicach poszukujących nowych sposobów angażowania młodych ludzi i pobudzania w nich empatii i zrozumienia dla istotnych procesów zachodzących na naszej planecie.

Osoby odwiedzające Eden mają również możliwość korzystania z przewodnika podczas zwiedzania każdego $\mathrm{z}$ trzech biomów. Przewodnik informuje np. o wielkim znaczeniu lasu deszczowego, ucząc, jak utrzymuje on naszą planetę przy życiu, a także jak my sami możemy pomóc w jego ochronie. Przedstawia też ciekawostki uprawy poszczególnych gatunków roślin, opowiada o sposobie życia mieszkańców danych stref klimatycznych, prezentując przy tym ich miejscowe chaty, wyposażenie i pożywienie.

Harmonogram imprez i szkoleń zmienia się w zależności od pór roku. Również sposób ich przedstawiania jest zależny od warunków atmosferycznych. Jeśli pogoda dopisuje, organizuje się na terenie Edenu wiele pokazów multimedialnych na wolnym powietrzu. Prowadzone są też kursy wspinaczki wysokogórskiej oraz liczne koncerty, opowieści na żywo, a w okresie zimowym nawet lodowisko. Na terenie ośrodka można również zorganizować imprezy dla dzieci, np. urodziny, a dorośli mogą w tej niezwykłej scenerii zorganizować własne przyjęcia, np. weselne.

Projekt Eden jest obiektem bardzo dużym i poza biomami obejmuje też olbrzymi obszar specjalistycznych ogrodów zewnętrznych. Czas zwiedzania jest nieograniczony i zależy jedynie od sprawności i zainteresowań poszczególnych osób.

W sąsiedztwie projektu Eden znajduje się bardzo duży parking podzielony na kilka poziomów oznaczonych wizerunkami i nazwami owoców, w celu lepszego odróżnienia i łatwego odnalezienia swojego samochodu. Z parkingu do przystanku końcowego przy strefie wejściowej, dowożą tu- rystów dość regularnie i często kursujące autobusy komunikacji wewnętrznej, których trasy przejazdu oznaczone są odpowiednimi nazwami owoców.

\section{Uwagi końcowe}

Projekt Eden jest ogromnym przedsięwzięciem, a pomysł wykorzystania nieczynnego wyrobiska górniczego zasługuje z pewnością na uwagę. Ponadto łączy on w sobie wiele interesujących funkcji: jest doskonałym miejscem zarówno edukacyjnym, jak i rozrywkowym. Śmiało może być nazwany ,żywym projektem”, gdyż zmienia swój wygląd i nigdy nie jest taki sam. Wraz z każdą następną porą roku zaskakuje widzów czymś innym. Wrażenie, jakie sprawia sama obecność kilkunastu tysięcy roślin przez cały rok wabiących swą barwą i zapachem, wzbogaca szum wody, śpiew ptaków czy wiatr. Wszystko to składa się na całość zaprojektowaną tak, aby oddziaływała na wszystkie zmysły. Swoistym dopełnieniem zwiedzania może być spożycie posiłku w okolicznych restauracjach, kawiarniach czy olbrzymich barach, położonych w strefie wejściowej, między biomami lasu deszczowego i śródziemnomorskiego, w których można zakosztować specjałów miejscowej kuchni, np. gorących, zapiekanych pierogów (tzw. pasties), sezonowych sałatek, ręcznie robionych rogalików czy regionalnego pieczywa. Wszystko to sporządzane jest w całości z ekologicznych składników.

Projekt Eden jest przede wszystkim ośrodkiem edukacyjnym, ukazującym jak bardzo jesteśmy zależni od roślin. Najlepiej odzwierciedla to największy z biomów, gdyż obszar lasów deszczowych o takiej samej powierzchni jest wycinany co 10 sekund. Wiedza ta pozwala uzmysłowić nam, że zgubne działanie na rzecz planety skutkuje wyrokiem na nas samych i dlatego właśnie rola edukacyjna tego ośrodka jest nie do przecenienia.

\section{References (Literatura)}

Bristow, C.M., 1996. Cornwall's geology and scenery. Cornish Hillside Publications, St. Austell, Cornwall.

Krawczyk, E., Lorenc, M.W., 2010. Problem niewykorzystanego potencjału dawnych kamieniołomów na przykładzie Wieżycy i Chwałkowa (Dolny Śląska). Geoturystyka-Geotourism, 21: 26-28.

Lorenc, M.W., 1994. Rola magm zasadowych w ewolucji intruzji granitoidowych (studium porównawcze wybranych masywów hercyńskich). Geologia Sudetica, 28: 3-121.

Lorenc, M.W., Cocks, A., 2008. Inscribing a landscape: the Cornish Mining World Heritage Site. Geoturystyka-Geotourism, 12: 27-40.

Pietrzyk-Sokulska, E., 2005. Kryteria i kierunki adaptacji terenów po eksploatacji surowców skalnych - studium dla wybranych obszarów Pol ski. Studia, Rozprawy, Monografie 131. Wydawnictwo Instytutu Gospodarki Surowcami Mineralnymi i Energią PAN Kraków.
Schwartz, S.P., 2006. Harnessing the Potential of the Cornish Overseas: A Preliminary Overseas Marketing Strategy for the Cornwall and West Devon Mining Heritage Site (WHS). Cornwall County Council, Truro.

Schwartz, S.P., Lorenc, M.W., 2011. From mining the landscape to mining wallets: mining heritage tourism in four European regions In: Słomka, T. (ed), Geotourism - A Variety of Aspects, AGH University of Science and Technology, Kraków and International Association for Geotourism, 261-295.

Skoczylas, J., 2008. Adaptacja dawnego kamieniołomu wapienia na Malcie dla potrzeb turystyki. Geoturystyka - Geotourism, 12: 41-48.

Smit, T., 2011. Eden, the whole inspiring story of the Eden Project. Edenproject Books. Somerset.

http://www.edenproject.com/ 